\title{
Tinjauan Filosofis Implementasi Pendidikan Agama Islam Dalam Peningkatan Sistem Religius Mahasiswa Universitas Singaperbangsa Karawang
}

\author{
Kafi Nurul Mursyidin ${ }^{1}$ \\ ${ }^{1}$ Universitas Singaperbangsa Karawang
}

\section{Info Artikel :}

Diterima 23 September, 2020

Direvisi 8 Oktober, 2020

Dipublikasikan 26 Oktober, 2020

\section{Kata Kunci: \\ Pendidikan \\ Agama Islam \\ Nilai Religius}

Keyword:

Education

Islamic Religious

Religious value

\begin{abstract}
ABSTRAK
Agama merupakan sumber dari nilai religius dan mempunyai keterkaitan yang sangat erat untuk masuk kedalam jiwa seseorang. Untuk membentuk manusia yang agamis dan mempunyai nilai-nilai religius dalam dirinya diperlukan pendidikan yang terarah. Sebuah lembaga pendidikan hendaknya mengenalkan dan menanamkan tauhid atau akidah kepada peserta didik sebagai pondasi awal sebelum peserta didik mengenal banyaknya disiplin ilmu lainnya. Dengan begitu para guru umunya dan guru pendidikan agama Islam khususnya untuk berupaya menciptakan budaya religius dan meningkatkan potensi religius guna membentuk kepribadian peserta didik menjadi manusia yang beriman, bertaqwa dan berakhlak. Pertanyaan dan tujuan dalam penelitian ini adalah untuk mengetahui proses implementasi pendidikan agama Islam dalam membangun nilai-nilai religius di lingkungan Fakultas Agama Islam Universitas Singaperbangsa Karawang Penelitian ini merupakan penelitian lapangan dengan menggunakan pendekatan deskriptif kualitatif. Sumber data yang digunakan dipilih secara purposive dan bersifat snowball sampling. Pengumpulan data dilakukan dengan teknik observasi, wawancara dan dokumentasi. Sedangkan analisis data dilakukan dengan analisis deskriptif.
\end{abstract}

\begin{abstract}
Religion is a source of religious value and has a very close relationship to enter into one's soul. To form a religious man and to have religious values in him directed education is needed. An educational institution should introduce and instill monotheism or creed to students as the initial foundation before students recognize the many other disciplines. That way the teachers generally and teachers of Islamic religious education in particular to try to create a religious culture and increase religious potential in order to shape the personality of students to be human beings who are faithful, devoted and moral. The questions and objectives in this study were to find out the process of implementing Islamic religious education in building religious values in the University Of Singaperbangsa Karawang This research is a field research using a qualitative descriptive approach. The data sources used were selected purposively and were snowball sampling. Data collection is done by observation, interview and documentation techniques. While data analysis was carried out by descriptive analysis. This analysis is used to present data in the form of a narrative or clearly described in the actual picture found by researchers in the field, namely about the implementation of Islamic education in building religious values in Muhammadiyah 3 Metro Middle School students.
\end{abstract}

This is an open access article distributed under the Creative Commons Attribution License, which permits unrestricted use, distribution, and reproduction in any medium, provided the original work is properly cited. C2019 by author.

\section{Koresponden:}

Kafi Nurul Mursyidin,

Email: kafinurul@staff.unsika.ac.id

\section{Pendahuluan}

Aktivitas manusia yang mencerminkan ketaatan dalam beribadah merupakan bentuk nilai religius terhadap tuhannya. Islam diyakini oleh seorang muslim sebagai agama yang memiliki nilai dan ajaran universal yang terkait erat dengan keberadaan al-Qur'an sebagai sumber pokok yang bersifat Ilahi, Transendental, dan meta-historis. Sunnah Rasul yang datang dari Nabi Muhammad saw sebagai pembawa risalah Islam, sampai derajat tertentu mengandung nilai-nilai universal dalam kehidupan 
manusia yang religius Untuk menjadikan nilai-nilai tersebut dapat diterima dalam kehidupan yang kongkrit, umat Islam dituntut untuk memahami makna yang dikandung dalam ajaran tersebut yaitu alQur'an dan as-Sunnah Rasul (hadits).

Pendidikan Agama Islam (PAI) pada Pergururan Tinggi memiliki kontribusi positif yang cukup efektif bagi pembentukan watak dan karakter bangsa yang bermartabat sejalan dengan tujuan pendidikan nasional (UU RI No. 20 tahun 2003 Tentang Sistem pendidikan Nasional pasal 3) yang menyatakan: "Pendidikan nasional bertujuan untuk berkembangnya potensi peserta didik agar menjadi manusia yang beriman dan bertakwa kepada Tuhan Yang Maha Esa, berakhlak mulia, sehat, berilmu,cakap, kreatif, mandiri, dan menjadi warga negara yang demokratis serta bertanggung jawab". Berikutnya pasal 12 ayat (1) dinyatakan bahwa "setiap peserta didik pada setiap satuan pendidikan berhak mendapatkan pendidikan agama sesuai dengan agama yang dianutnya dan diajarkan oleh pendidik yang seagama".

Landasan konstitusional di atas, mengingatkan bahwa pendidikan agama, khususnya agama Islam, di Pergururan Tinggi cukup menempati posisi strategis dalam mendukung pembangunan nasional, khususnya terhadap aspek pembangunan sumber daya manusia Indonesia. Pada tataran yang lebih substansial, pendidikan Islam di Pergururan Tinggi juga diharapkan dapat menjadi sarana pendidikan keimanan, ketaqwaan yang tercermin dalam sikap religius, seperti ketaatan beribadah serta karakter mahasiswanya, khususnya mahasiswa Universitas Singaperbangsa Karawang (Unsika). Dalam Islam, sikap dan prilaku menempati kedudukan penting dan dianggap memiliki fungsi yang urgent dalam memandu kehidupan keluarga, sekolah, masyarakat, berbangsa dan bernegara.

\section{Studi Kepustakaan}

\section{Tinjauan Filosofis}

Tiga dimensi tinjauan filosofis terhadap ilmu pengetahuan menurut Jujun S. Suriasumantri yaitu ontologi yang berbicara mengenai apa hakekat pengetahuan itu. Epistemologi yang menuntut kita bagaimana cara mendapatkan ilmu pengetahuan dan yang terakhir adalah aksiologi yang membicarakan untuk apa pengetahuan itu dipergunakan. Berdasarkan dari hal di atas maka penulis akan menguraikan secara singkat ketiga dimensi tersebut.

a. Ontologi; Ontologi merupakan cabang filsafat yang berupaya mendeskripsikan hakekat wujud. Ontologi digunakan sebagai sinonim untuk metafisika dan disebut sebagai filsafat pertama.

b. Epistemologi; Epistemologi adalah pengetahuan tentang pengetahuan. Hakekat keilmuan ditentukan oleh cara berpikir yang dilakukan menurut syarat keilmuan yaitu bersifat terbuka dan menjunjung kebenaran di atas segala-galanya.

c. Aksiologi; aksiologi adalah teori nilai yang berkaitan dengan kegunaan dari pengetahuan yang diperoleh.

\section{Pengertian Implementasi}

Menurut Nurdin Usman (2002:70), Implementasi bermuara pada aktivitas, aksi, tindakan, atau adanya mekanisme suatu sistem. Implementasi bukan sekedar aktivitas, tetapi suatu kegiatan yang terencana dan untuk mencapai tujuan kegiatan. Sedangkan Menurut Pressman \& Wildavsky (1873), Implementasi adalah accomplishing, fulfillng, carrying out, producing, and completing a policy, artinya (menyelesaikan, memenuhi, melaksanakan, memproduksi, seta menyelesaikan sebuah kebijakan). Begitupun menurut Harsono (2002 : 67) Implementasi adalah suatu proses untuk melaksanakan kebijakan menjadi tindakan kebijakan dari politik ke dalam administrasi. Pengembangan kebijakan dalam rangka penyempurnaan suatu program. Guntur Setiawan (2004) Pengertian implementasi adalah perluasan dari aktivitas yang saling menyesuaikan proses interaksi antara tujuan serta tindakan dengan tujuan untuk menggapainya juga diperlukan jaringan pelaksana berokrasi yang efektif.

\section{Hakikat Pendidikan Agama Islam}

Pengertian pendidikan itu bermacam-macam, hal ini disebabkan karena perbedaan filosofi hidup yang dianut dan sudut pandang yang memberikan rumusan tentang pendidikan itu. Sahertian (2000:1) mengatakan, bahwa pendidikan adalah "usaha sadar yang dengan sengaja dirancangkan untuk mencapai tujuan yang telah ditetapkan". Sedangkan Ihsan mengatakan bahwa "Pendidikan merupakan usaha manusia untuk menumbuhkan dan mengembangkan potensi-potensi pembawaan baik jasmani maupun rohani sesuai dengan nilai-nilai yang ada di dalam masyarakat dan kebudayaan. Atau dengan kata lain bahwa pendidikan dapat diartikan sebagai suatu hasil peradaban bangsa yang dikembangkan atas dasar pandangan hidup bangsa itu sendiri (nilai dan norma masyarakat) yang berfungsi sebagai filsafat pendidikannya atau sebagai cita-cita dan pernyataan tujuan pendidikannya" (Ihsan, 1996:1). 
Sehingga Pendidikan Agama Islam berarti "usaha-usaha secara sistematis dan pragmatis dalam membantu anak didik agar mereka hidup sesuai dengan ajaran Islam" (Zuhairani, 1983 : 27). Secara lebih nyata, pendidikan agama Islam dapat didefenisikan sebagai upaya untuk mengaktualkan sifat-sifat kesempurnaan yang telah dianugerahkan oleh Allah Swt kepada manusia, upaya tersebut dilaksanakan tanpa pamrih apapun kecuali untuk semata-mata beribadah kepada Allah (Bawani, 1993 : 65).

Ada juga yang menyebutkan bahwa pendidikan agama Islam adalah sebagai proses penyampaian informasi dalam rangka pembentukan insan yang beriman dan bertakwa agar manusia menyadari kedudukannya, tugas dan fungsinya di dunia dengan selalu memelihara hubungannya dengan Allah Swt, dirinya sendiri, masyarakat dan alam sekitarnya serta tanggung jawab kepada Tuhan Yang Maha Esa termasuk dirinya sendiri dan lingkungan hidupnya (Ali, 1995: 139).

Tujuan Pendidikan Agama Islam dibagi menjadi dua bagian, dengan uraian sebagai berikut :

a. Tujuan Umum

Tujuan umum Pendidikan Agama Islam adalah untuk mencapai kwalitas yang disebutkan oleh alQur'an dan hadits, sedangkan fungsi pendidikan nasional adalah mengembangkan kemampuan dan membentuk watak serta peradaban bangsa yang bermartabat dalam rangka mencerdaskan kehidupan bangsa, bertujuan untuk mengembangkan potensi peserta didik agar menjadi manusia yang beriman dan bertakwa kepada Tuhan Yang Maha Esa, berakhlak mulia, sehat, berilmu, cakap, kreatif, mandiri, dan menjadi warga negara yang demokratis serta bertanggung jawab.

\section{b. Tujuan Khusus}

Tujuan khusus Pendidikan Agama Islam adalah tujuan yang disesuaikan dengan pertumbuhan dan perkembangan pesrta didik atau mahasiswa sesuai dengan jenjang pendidikan yang dilaluinya, sehingga setiap tujuan Pendidikan Agama Islam pada setiap jenjang pendidikan mempunyai tujuan yang berbedabeda, seperti tujuan Pendidikan Agama Islam di sekolah dasar berbeda dengan tujuan Pendidikan Agama Islam di SMP, SMA dan berbeda pula dengan tujuan Pendidikan Agama Islam di perguruan tinggi.

Tujuan khusus pendidikan seperti di perguruan timggi adalah untuk meningkatkan kecerdasan, pengetahuan, kepribadian, akhlak mulia, keterampilan untuk hidup mandiri dan membiasakan perilaku terpuji dan menjauhkan diri dari perilaku (Riyanto, 2006 : 160). Sedangkan tujuan lain adalah untuk menjadikan peserta didik agar menjadi pemeluk agama yang aktif dan menjadi masyarakat atau warga negara yang baik dimana keduanya itu terpadu untuk mewujudkan apa yang dicita-citakan merupakan suatu hakekat, sehingga setiap pemeluk agama yang aktif secara otomatis akan menjadi warga negara yang baik, terciptalah warga negara yang baik dan berketuhanan Yang Maha Esa.

\section{Kedudukan Pendidikan Agama Islam di Perguruan Tinggi}

Dalam kurikulum Perguruan Tinggi Umum, matakuliah Pendidikan Agama merupakan bagian integral dari kurikulum nasional dan dikelompokkan ke dalam Matakuliah Pengembangan Kepribadian (MPK), bersama matakuliah yang lainnya, yaitu Pancasila dan Kewarganegaraan. Oleh karenanya, matakuliah Pendidikan Agama memiliki peran penting dalam membina kepribadian mahasiswa sebagai calon sarjana Indonesia yang beriman dan bertakwa serta memiliki integritas kepribadian yang tinggi.

Berdasarkan SK Mendiknas No.232/U/2000, Pendidikan Agama Islam (PAI) sebagai MPK mempunyai kedudukan yang sama dengan matakuliah lain yang termasuk MPK inti yang wajib diberikan dalam kurikulum setiap program studi. MPK mempunyai visi dan misi. Visi MPK adalah menjadi sumber nilai dan pedoman bagi penyelanggaraan program studi dalam mengantarkan mahasiswa mengembangkan kepribadiannya. Sedangkan misinya adalah membantu mahasiswa, agar mampu mewujudkan nilai dasar agama dan kebudayaan serta kesadaran berbangsa dan bernegara dalam menerapkan ilmu pengetahuan, teknologi, dan seni yang dikuasainya dengan rasa tanggung jawab kemanusiaan. Visi dan Misi tersebut dijabarkan ke dalam kompetensi MPK yaitu menguasai kemampuan berpikir, bersikap rasional dan dinamis, serta berpandangan luas sebagai manusia intelektual.

Karena kedudukannya yang sangat strategis, maka Pendidikan Agama Islam harus mendapatkan perhatian yang sangat serius. Terlebih para lulusan Perguruan Tinggi sangat berpeluang besar untuk tampil menjadi para pemimpin bangsa di masa depan atau juga sebaliknya, mereka berpotensi untuk menjauhkan masyarakat dari nilai-nilai agama dan budaya bangsa. Oleh karena itu, sebagai mahasiswa Islam seharusnya di dalam diri mereka tertanam kesadaran yang mendalam dan semangat yang besar akan wajibnya melakukan pembelajaran dan kajian terhadap ajaran Islam.

\section{Karakteristik dan Model Pembeleajaran PAI di Perguruan Tinggi}


Setiap mata pelajaran memiliki ciri khas atau karakteristik tertentu yang dapat membedaknnya dengan mata pelajaran lainnya, begitu juga halnya mata pelajaran PAI. Karakteristik mata pelajaran PAI, sebagaimana dijelaskan dalam buku pedoman khusus PAI (Depdiknas, 2002) adalah sebagai berikut:

a. PAI merupakan mata kuliah yang dikembangkan dari ajaran-ajaran pokok agama Islam;

b. PAI Bertujuan membentuk peserta didik agar beriman dan bertakwa kepada Allah Swt, serta memiliki akhlak mulia;

c. PAI mencakup tiga kerangka dasar, yaitu aqidah, syari ah, dan akhlak. Aqidah merupakan penjabaran dari konsep iman; syari ah merupakan penjabaran dari konsep Islam, syari ah memiliki dua dimensi kajian pokok, yaitu ibadah dan muamalah; dan akhlak merupakan penjabaran dari konsep ihsan.

Karakteristik peserta didik dapat dilihat dari kemampuan peserta didik sesuai usia perkembangannya, kebutuhan, motivasi, dan keunikan gaya belajar masing-masing peserta didik. Penerapan suatu model harus memperhatikan juga faktor kemampuan guru, sebaik apapun sebuah model pembelajaran tidak akan berjalan efektif apabila guru tidak mampu menguasai model tersebut.

Perihal pemilihan model pembelajaran, sejatinya pemilihan model pembelajaran yang tepat akan menentukan tingkat keberhasilan belajar peserta didik, namun tidak setiap model pembelajaran dapat diterapkan begitu saja tanpa mengindahkan beberapa faktor. Sukmadinata (2004: 151-154) mengemukakan empat faktor yang harus diperhatikan guru atau dosen dalam memilih model pembelajaran, yaitu tujuan pembelajaran, karakteristik mata pelajaran, kemampuan peserta didik, dan kemampuan pendidik.

Hakikat Sikap Religius

Sikap atau attitude dapat dibedakan dalam attitude sosial dan attitude individual. Ada beberapa pengertian sikap yang telah dirumuskan oleh para ahli antara lain, yaitu:

a. Menurut Dr. W.A. Gerungan (1998: 1500, bahwa attitude ini lebih tepat diterjemahkan sebagai sikap dan kesediaan beraksi terhadap suatu hal.

b. Sarlito Wirawan (1996: 94), berpendapat bahwa sikap adalah kesiapan kepada seseorang untuk bertindak secara tertentu terhadap hal-hal tertentu.

c. Mayor Polak (1979: 97), berpendapat bahwa sikap adalah suatu tendensi atau kecenderungan yang agak stabil untuk berlaku atau bertindak secara tertentu di dalam situasi yang tertentu.

d. Menurut Kamus Psikologi (Kartini Kartono dan Dali Gula, 1982: 35), sikap diartikan sebagai kecenderungan untuk memberi respon, baik positif maupun negatif terhadap orang-orang, benda-benda atau situasi-situasi tertentu.

Adapun faktor-faktor yang mempengaruhi sikap, diantaranya adalah:

a. Pengalaman pribadi

Pengalaman ini menjadi sumber suatu sikap (attitude origins), sikap yang terbentuk berdasarkan pengalaman langsung sering kali memberikan pengaruh yang lebih kuat pada tingkah laku daripada sikap yang terbentuk berdasarkan pengalaman tidak langsung atau pengalaman orang lain.

b. Pengaruh orang lain yang dianggap penting

Orang yang biasanya dianggap penting bagi individu adalah orang tua, orang yang status sosialnya lebih tinggi, teman sebaya, teman dekat, guru, teman kerja, istri atau suami dan lain-lain.

c. Pengaruh kebudayaan

Kebudayaan di mana seseorang hidup dan dibesarkan mempunyai pengaruh besar terhadap pembentukan sikap seseorang. Apabila sesorang hidup dalam budaya sosial yang sangat mengutamakan kehidupan berkelompok maka sangat mungkin orang tersebut akan mempunyai sikap negatif terhadap kehidupan individualisme yang sangat mengutamakan kepentingan perorangan. Kebudayaan telah menanamkan garis pengarah sikap terhadap berbagai masalah.

d. Media massa

Media massa sebagai sarana komunikasi mempunyai pengaruh besar dalam pembentukan opini dan kepercayaan orang. Adanya informasi baru mengenai sesuatu hal memberikan landasan kognitif baru bagi terbentuknya sikap terhadap hal tersebut.

e. Lembaga pendidikan dan lembaga agama

Lembaga pendidikan serta lembaga agama sebagai suatu sistem mempunyai pengaruh dalam pembentukan sikap dikarenakan keduanya meletakkan dasar pengertian dan konsep moral dalam diri individu.

f. Pengaruh faktor emosional

Tidak semua bentuk sikap ditentukan oleh situasi lingkungan dan pengalaman pribadi seseorang. Kadangkadang, suatu bentuk sikap merupakan pernyataan yang didasari oleh emosi yang berfungsi sebagai 
semacam penyaluran frustasi atau pengalihan bentuk mekanisme pertahanan ego. Sikap demikian dapat merupakan sikap sementara dan segera berlalu begitu frustasi telah hilang akan tetapi dapat pula merupakan sikap yang lebih bersistem dan bertahan lama.

\section{Metode Penelitian}

\section{Tempat dan Waktu Penelitian}

Penelitian ini dilaksanakan di Universitas Singaperbangsa Karawang (Unsika) yang berlokasi di Jalan HS. Ronggo Waluyo, Puseurjaya, Telukjambe Timur, Kabupaten Karawang, Jawa Barat 41361. Universitas Singaperbangsa Karawang. Waktu Penelitian ini dilaksanakan selama 6 (enam) bulan yang dimulai sejak minggu pertama di bulan Mei sampai akhir bulan Nopember 2019.

\section{Metode Penelitian, Jenis dan Sumber Data}

Metode penelitian yang peneliti gunakan untuk mencari kebenaran tentang masalah yang hendak dicari adalah metode penelitian kualitatif. Sebagimana menurut Sugiono (2011: 15), bahwa "metode penelitian kualitatif adalah metode penelitian yang berlandaskan pada filsafat postpositivisme, digunakan untuk meneliti pada kondisi obyek yang alamiyah (sebagai lawannya eksperiment) dimana peneliti adalah sebagai instrument kunci, pengambilan sampel sumber data dilakukan secara purposive dan snowball, teknik pengumpulan dengan triangulasi (gabungan), analisis data bersifat induktif/kualitatif, dan hasil penelitiak kualitatif lebih menekankan makna dari pada generalisasi".

Adapun jenis data yang dikumpulkan berupa data yang bersifat kualitatif yang terdiri dari data primer dan data sekunder tentang implemenasi Pendidikan Agama Islam dalam meningkatkan sikap religius. Sedangkan sumber data pada penelitian ini adalah Dekan di Lingkungan Unsika, Team Teaching MKWU-PAI, dan Mahasiswa Unsika serta data-data hasil pengamatan dan data-data yang berupa dokumen tertulis. Dengan demikian, jenis dan sumber data dalam penlitian ini terdiri dari dua, yaitu:

a. Data primer

Data ini bersumber dari responden yang langsung ditemui di lapangan (lokasi penelitian) yang diperoleh melalui wawancara dengan Dekan, Team Teaching MKWU-PAI, dan Mahasiswa Unsika.

b. Data Sekunder

Data sekunder ini berupa hasil pengamatan di lapangan (lokasi penelitian) dan data-data tertulis, seperti visi, misi dan profil Unsika, data Team Teaching MKWU-PAI, dan lain sebagainya yang diperoleh melalui observasi dan studi dokumentasi.

\section{Teknik Pengumpulan Data}

Untuk memperoleh data yang dibutuhkan dalam penelitian ini digunakan teknik pengumpulan data sebagai berikut:

a. Wawancara

Teknik wawancara yang digunakan adalah teknik wawancara tidak terstruktur, namun peneliti tetap membuat desain wawancara agar alur wawancara tidak terlalu jauh dari tema dan pengumpulan data yang diharapkan oleh peneliti. Pada penelitian kali ini wawancara dilaksanakan kepada Dekan, dan Team Teaching MKWU-PAI. Data hasil wawancara ini digunakan untuk mendapatkan informasi tentang penerapan pendidikan karakter yang dilakukan kepala sekolah.

\section{b. Observasi}

Jenis observasi yang peneliti lakukan adalah jenis pengamatan secara langsung dan terbuka di Universitas Singaperbangsa Karawang (Unsika). Pengamatan langsung atau terbuka adalah jenis observasi yang diketahui oleh subjek. Sehingga dalam penelitian ini, peneliti melakukan pengamatan terhadap civitas akademik Unsika. Instrumen yang digunakan dalam teknik ini adalah pedoman observasi berupa daftar catatan. Tujuannya adalah untuk menambah data yang dapat dijadikan bahan dalam menyusun informasi.

\section{c. Studi Dokumentasi}

Selain melakukan wawancara dan observasi, peneliti juga melakukan teknik studi dokumentasi. Studi dokumentasi adalah teknik untuk mencari dan mengumpulkan data yang berupa data-data tertulis, seperti catatan, transkip, buku, notulen, transkip nilai, agenda dan sebagainya.

\section{HASIL PENELITIAN DAN PEMBAHASAN}

\section{Hasil Penelitian}

a. Karakter Religius Mahasiswa Universitas Singaperbangsa Karawang 
Nilai religius merupakan dasar dan pedoman bagi seseorang untuk beragama, maka penting kiranya seorang muslim untuk menerapkan nilai-nilai religius tersebut dalam kehidupannya. Dengan begitu ketika nilai-nilai religius tersebut telah tertanam dalam dirinya maka akhlak yang baik dan kehidupan yang baik pun akan mengiringinya.Begitupun dengan peserta dididik dikampus, maka tugas dan tanggung jawab lembaga pendidikan semuanya mempunyai tanggungjawab yang besar untuk menjadikan lembaga tersebut atau sekolah tersebut menjadi sebuah lembaga yang mempunyai program-program dan pembiasaan-pembiasan yang baik guna menjadikan budaya religius di sekolah dan menjadikan peserta didik yang berakhlak dan bertaqwa kepada Allah SWT.

Terbentuknya karakter religius yang baik terhadap mahasiswa merupakan dampak yang paling urgent yang diharapkan di Universitas Singaperbangsa Karawang. Hal ini dapat dilihar dalam 3 aspek yaitu: spriritual, sosial dan pengetahuan. Pertama: karakter religius in berdampak pada peningkatan kualitas spiritual siswa, yaitu bertambahnya keimanan dan ketaqwaan kepada Allah SWT, Memiliki Akidah yang kuat, berpegang teguh pada syariat islam. Para siswa-siswi mempunyai akhlak yang mulia dan memiliki karakter yang baik. Hal ini sesuai dengan teori Aspek religius menurut Kementerian Lingkungan Hidup RI 1987 religiusitas (Agama Islam) terdiri dari lima apek: Kedua, Sosial, jadi implementasi Pembelajaran PAI dalam membentuk kepedulian sosial, berdampak pada ucapan dan perbuatan, memiliki sikap kepedulian pada orang lain, seperti ucapan rasa terima kasih, saling menghargai, salaman, rasa persatuan, infaq dan shodaqoh, toleransi, menjenguk teman/ orangtua yang sakit, santunan anak yatim, memberikan sumbangan baju setelah kelulusan Sekolah, kerja bakti di lingkungan kampus, Pendidikan Sistem Ganda (PSG) dan saling membantu di lingkungan kampus. Ketiga, pengetahuan berdampak pada keilmuan siswa yaitu memahami ilmu agama dan umum. kesempatan peserta didik untuk memiliki wawasan integral. Namun, dalam kenyataannya pengetahuan siswa dalam bidang umum lebih dominan daripada pengetahuan agama.

Berdasarkan paparan di atas, yang menarik dari Universitas Singaperbangsa Karawang adalah dapat mengembangkan ketiga komponen di atas, sehingga memilki kualitas yang baik serta dapat memberikan kepuasan pelanggan baik dari masyarakat maupun orang tua siswa. hal tersebut berupa: (1) memiliki akhlakul karimah atau karakter yang baik, (2) memiliki wawasan integral (imtaq dan iptek), serta dapat meluluskan siswa, (3), memiliki jiwa wirausaha dan diterima didunia kerja (4), dapat melanjutkan ke jenjang yang lebih tinggi dan dapat diterima di Universitas Negeri.

a) Implementasi Pembelajaran PAI dalam membentuk sikap religius di Universitas Singaperbangsa Karawang.

1) Perencanaan Pembelajaran Pendidikan Agama Islam dalam pembentukan sikap Religius di Universitas Singaperbangsa Karawang.

Perencanaan merupakan salah satu hal yang penting yang perlu dilakukan dalam setiap akan melakukan suatu kegiatan, karena perencanaan merupakan awal dari sebuah pelaksanaan dan menentukan tujuan yang akan dicapai. Berdasarkan hasil temuan peneliti dilapangan bahwa peneliti dilapangan bahwa perencanaan pembelajaran PAI dalam pembentukan sikap religius di Universitas Singaerbangsa Karawang adalah: Dosen PAI sebelum melakukan pelaksanaan mengadakan rapat penentuan jenis kegiatan, waktu, dan tempat dalam rapat koordinasi di fakultas, setelah itu baru disosialisasi kepada seluruh dosen dan mahasiswa tentang program yang di lakukan. Peran guru PAI dalam mengimplementasikan pembelajaran PAI untuk pembentukan karakter religius dan kepedulian sosial di SMK Negeri 1 Kota Batu sangatlah dibutuhkan agar dapat terselenggaranya keiatan kegiatan dengan baik. Hal tersebut sesuai dengan yang dijelaskan oleh Fathurrahman bahwa guru adalah tenaga pendidik yang memberikan sejumlah ilmu pengetahuan kepada siswa di sekolah, selain ilmu pengetahuan guru juga bertugas menanamkan nilai-nilai dan sikap kepada siswa agar memiliki kepribadian yang paripurna.

2) Implementasi Pendidikan Agama Islam dalam Peningkatan Sikap Religius di Universitas Singaperbangsa Karawang

Pelaksanaan Pembelajaran Pendidikan Agama Islam (PAI) dalam membentuk sikap religius di Universitas Singaperbangsa Karawang dilakukan dan tentunya diperlukan adanya koordinasi dan kerjasama dari berbagai pihak, baik dari Dekan Fakultas, Dosen-dosen PAI Khususnya dan seluruh guru-guru umumnya serta seluruh siswa. Implementasi pembelajaran PAI dalam pembentukan sikap religius di Universitas Singaperbangsa Karawang yang diintegrasikan dalam pembelajaran sedah dikembangkan oleh Kementerian Ristek dan Pendidikan Tinggi, dalam hal ini Mulyasa menjelaskan bahwa design kurikulum yang dikembangkan oleh kemenristek, yaitu kurikulum holistik (Menyeluruh), berbasis karakter 
(character based integrated curriculum). Kurikulum terpada yang menyentuh semua aspek kebutuhan anak dan dapat merefleksiakan dimensi keterampilan, dengan menampilkan tema-tema yang kontekstual. Kurikulum ini mengembangkan kecakapan hidup yang melibatkan kemampuan personal, sosial, logika, dan motorik. Sedangkan menurut Muchlas pendidikan karakter adalah penanaman nilai-nilai karakter kepada manusia yang meliputi komponen pengetahuan, kesadaran atau kemauan dan tindakan untuk melaksanakan nilainilai baik terhadap Tuhan, diri sendiri, sesama, lingkungan maupun kebangsaan sehingga bisa menjadi insan kamil.

\section{Pembahasan}

Setelah data dipaparkan secara narasi dan menghasilkan temuan-temuan maka langkah selanjutnya yaitu mengkaji hakikat dan makna temuan dari penelitian tersebut. Masing-masing temuan penelitian akan dibahas mengacu pada teori dan pendapat para ahli yang sesuai, agar benar-benar dapat menjadikan setiap temuan tersebut kokoh dan layak untuk dibahas.

a. Membangun Nilai-Nilai Religius

Religius menurut Islam adalah melaksanakan segala sesuatu yang telah diperintahkan dan diajarkan dalam syari'at Islam, baik dari tingkah laku, bertutur kata, dan bersikap. Dan semata-mata hal tersebut dilakukannya untuk beribadah kepada Allah SWT. Perintah tersebut mengharuskan bagi setiap muslim untuk selalu berIslam dimanapun tempat dan segala keadaan apapun tanpa tekecuali. Implementasi dari nilai-nilai religius yang dilakukan oleh dosen pendidikan agama Islam di Unsiversitas Singaperbangsa Karawang yiatu dengan memberikan arahan maupun nasihat kepada mahasiswa dengan cara diantaranya mengajarkan untuk selalu berkata yang sopan, berprilaku yang baik, memberikan keteladanan yang baik supaya mahasiswa dapat mencontohnya dengan berbagai cara seperti menghormati orang lain baik dengan orang yang lebih tua maupun dengan yang lebih muda sekalipun. Agar nilai-nilai religius tahan lama maka harus ada proses pembudayaan nilai-nilai religius. Untuk membentuk budaya religius dapat dilakukan oleh praktisi pendidikan diantaranya melalui:

a) Memberikan contoh (Teladan)

b) Membiasakan hal-hal yang baik

c) Menegakkan disiplin

d) Memberikan motivasi dan dorongan

e) Memberikan hadiah terutama psikologis

f) Menghukum dalam rangka kedisplinan

g) Menciptakan suasana religius yang berpengaruh pada pertumbuhan anak

Upaya yang dilakukan oleh pihak kampus terutama yang dilakukan oleh guru pendidikan agama Islam dalam mempertahankan budaya religius ini yaitu mengaplikasikannya dalam bentuk kegiatan keseharian berupa pembiasaan-pembiasaan yang harus dilakukan mahasiswa seperti: membiasakan budaya salam dan disertai dengan berjabat tangan kepada guru dan teman-temannya ketika bertemu, berinfaq setiap hari jum'at, membudayakan membaca Al-Qur'an satu jam sebelum dimulai pembelajaran, membiasakan sholat dhuha berjama'ah, membiasakan sholat dhuhur berjama'ah, kemudian mengikuti kajian atau ceramah yang dilakukan setiap hari sabtu selepas sholat dhuhur, penambahan kegiatan pada saat bulan Ramadhan, dan kita juga ada kegiatan tahunan yaitu kegiatan sosial dimana memberikan santunan anak yatim pada hari raya idul fitri dan pembagian daging kurban juga pada saat hari raya idul adha.

Kemudian kedisiplinan bagi semua warga kampus pun diterapkan di Universitas Singaperbangsa Karawang ini dimulai dari kerapihan berpakaian, ketepatan waktu dan sangsi-sangsi yang akan diberikan kepada semua mahasiswa ketika melakukan pelanggaran terhadap peraturan kampus.

Pada dasarnya peran dari kampus itu sendiri yaitu sebagai sebuah lembaga pendidikan yang membantu lingkungan keluarga. Dan untuk mencapai tujuan tersebut semua warga kampus baik itu Rektor, pendidik bahkan pegawai harus bekerjasama dan berupaya semaksimal mungkin untuk dapat menciptakan lingkungan sekolah yang agamis, kondusif, harmonis dan juga dapat menjadi suri tauladan bagi peserta didik.

\section{Kesimpulan}

Berdasarkan hasil penelitian dan pembahasan dapat ditarik kesimpulan bahwa implementasi pendidikan agama Islam dalam membangun nilai-nilai religius Mahasiswa di Universitas Singaperbangsa Karawang yaitu:

Implementasi pendidikan agama Islam dalam membangun nilai-nilai religius di lingkungan Universitas Singaperbangsa Karawang dilakukan dengan baik dan efektif dengan diterapkannya dalam kegiatan 
keseharian seperti membiasakan mengucapkan salam, berjabat tangan, santun dalam berbicara, sopan dalam bersikap, dan saling menghormati baik dengan dosen maupun sesama teman.

Kemudian terkait program-program dalam kurikulum khusus mengenai keagamaan, kultum bagi lakilaki dan juga adanya ceramah atau kajian yang dilakukan setiap hari sabtu selepas sholat dhuhur, infaq setiap hari jum'at dan juga menghafalkan surat-surat pilihan dalam Al-Qur'an, kemudian keteladan dan kedisiplinan yang diberikan oleh semua warga sekolah. Program dan pengkondisian sekolah yang ciptakan sedemikian rupa tersebut dilakukan dengan harapan dapat menjadikan peserta didik yang beriman, taat kepada Allah SWT, berakhlakul karimah, dan memiliki jiwa sosial yang baik..

\section{Referensi}

Ali Ashraf dalam Bukhari Umar, 2010, Ilmu Pendidikan Islam, Jakarta: Amzah Bawani, 2012, Belajar dan Pembelajaran Pendidikan Agama islam, Bandung: Remaja Rosdakarya.

Gerunja, 2013, Pemikiran Pendidikan Islam, Bandung: Trigenda Karya.

Guntur Setiawan, 2010, Madrasah dan Pendidikan Anak Bangsa, Jakarta:

Raja Grafindo Persada.

Abudin Nata, 2001, Paradigma Pendidikan Islam: (Kapita Selekta Pendidikan

Aagma Islam, Jakarta: PT Gramedia.

Agus Maimun dan Agus Zainul Fitri, 2010, Madrasah Unggulan Lembaga Pendidikan Alternatif di

Era Kompetitif, Malang : UIN MALIKI PRESS.

Ahmad Tafsir, 2004, $\quad$ Ilmu Pendidikan dalam Perspektif Islam, Bandung: PT.

Remaja Rosdakarya.

Rosdakarya.

Ali Ashraf dalam Bukhari Umar, 2010, Ilmu Pendidikan Islam, Jakarta: Amzah.

Armai Arief, 2002, Pengantar Ilmu dan Metodologi Pendidikan Islam, Jakarta, Ciputat Pers, cet 1.

Bahudji, 2012, Bahan Ajar Metodologi Studi Islam, Metro: STAIN Metro.

Beni Ahmad Saebani, dkk, 2009, Ilmu Pendidikan Islam, Bandung: Pustaka Setia, Chairul Anwar,

2014, Hakikat Manusia dalam Pendidikan;Sebuah Tinjauan Filosofis, Yogyakarta: SUKA-Press.

Deddy Mulyana, 2010, Metodologi Penelitian Kualitatif Paradigma Baru Ilmu Komunikasi dan

Ilmu Sosial Lainnya, Bandung: PT Remaja Rosdakarya.

Departemen Agama Republik Indonesia, 2006, Al-Qur'an dan Terjemahannya, Jakarta: Pustaka

Agung Harapan.

Departemen Pendidikan Nasional, 2003, Standar Kompetensi Mata Pelajaran Pendidikan Agama

Islam SMP dan MTs, Jakarta : Pusat Kurikulum. Edi

Kusnadi, 2008, Metodologi Penelitian, Jakarta, Metro: Ramayana Press dan STAIN Metro.

JS Badudu, Sutan Muhammad Zain, 2004, Kamus Umum Bahasa Indonesia, Jakarta: Pustaka Sinar Harapan.

KEMENDIKBUD, Pengantar Umum SILABUS PAI Kurikulum 2013, Jakarta.

Kunandar, 2007, Guru Profesional Implementasi Kurikulum Tingkat Satuan Pendidikan (KTSP)

dan Sukses dalam Sertifikasi Guru, Jakarta : Raja Grafindo Persada.

Lexy J. Moleong, 2001, Metodologi Penelitian Kualitatif, Bandung: PT Remaja Rosdakarya.

Mansur Muslich, 2011, Pendidikan Karakter Menjawab Krisis Multimedia Nasional, Jakarta, PT Bumi Aksara.

Margono, 2010, Metodologi Penelitian Pendidikan, Jakarta: Rineka Cipta.

Muhaimin, 2012, Paradigma Pendidikan Islam: Upaya

Mengefektifkan

Pendidikan Agama Islam di Sekolah, Bandung: Remaja Rosdakarya.

Persada.

--o---, 2012, Pemikiran dan Aktualisasi Pengembangan Pendidikan Islam,

Jakarta: PT. Raja Grafindo Persada.

-, 2005, Pengembangan Kurikulum Pendidikan Agama Islam, Jakarta :

PT. Raja Grafindo Persada.

Muhammad Muntahibun Nafis, 2011, Ilmu Pendidikan Islam, Yogyakarta: Teras.

Muhibbin Syah, 2010, Psikolgi Pendidikan dengan Pendekatan Baru, Bandung:

PT. Remaja Rosdakarya.

Mukhtar, 2003, Desain Pembelajaran Pendidikan Agama Islam, Jakarta: Misika

Galiza. 
Mukhtar, 2013, Metode Praktis Penelitian Deskriptif Kualitatif, Jakarta : Referensi. Mustofa, 2011, Akhlak Tasawuf, Bandung: CV. Pustaka Setia.

Ngainun Naim, 2012, Character Building Optimalisasi Peran Pendidikan Dalam Pengembangan Ilmu Dan Pembentukan Karakter Bangsa, Jogjakarta : Arruz Media

Qodri Azizy, 2013, Pendidikan Untuk Membangun Etika Sosial (Mendidik Anak Sukses Masa Depan: Pandai dan Bermanfaat), Semarang: Aneka Ilmu, cet.

Ramayulis, 2002, Ilmu Pendidikan Islam, Jakarta: Kalam Mulia, Cet. XI.

---------, 2014, Ilmu pendidikan Islam, Jakarta: Kalam Mulia. 2005, Metedologi Pendidikan Agama Islam, Jakarta: Kalam Mulia.

Rois Mahfud, 2010, Al-Islam (Pendidikan Agama Islam), Jakarta: Erlangga.

Sisdiknas, 2010, Undang-Undang SISDIKNAS (Sistem Pendidikan Nasional),

Bandung: Fokus Media.

Sjarkawi, 2008, Pembentukan Kepribadian Anak, Jakarta: Bumi Aksara.

Sugiyono, 2014, Memahami Penelitian Kualitatif, Bandung: CV. Alfabeta.

-----, 2008, Metode Penelitian Pendidikan, Pendekatan Kuantitatif,

Kualitatif dan R\&D, Bandung: Alfabeta.

Suharsimi Arikunto, 2010, Prosedur Penelitian Suatu Pendekatan Praktik, Jakarta: PT Rineka Cipta.

Sutrisno , 2003, Metodologi Research, Yogyakarta: Bumi Aksara.

Tim Penyusun Kamus Pusat Pembinaan dan Pengembangan Bahasa Departemen Pendidikan dan

Kebudayaan, 2004, Kamus Besar Bahasa Indonesia, Jakarta, Balai Bustaka, Edisi Kedua.

Undang-Undang Sistem Pendidikan Nasional (Nomor 20 Tahun 2003), Bandung:

Fokusmedia, 2003.

Zakiah Daradjat, 2010, Ilmu Jiwa Agama, Jakarta: Bulan Bintang.

------------, 2015, Metodik Khusus Pengajaran Agama Islam, Jakarta: Bumi Aksara.

dkk, 2012, Ilmu Pendidikan Islam, Jakarta: Bumi Aksara, Cet, Zuhairini, dkk, 2015,

Filsafat Pendidikan Islam, Jakarta: Bumi Aksara, Cet v.

Zulkarnain, 2008, Transformasi Nilai-Nilai Pendidikan Islam, Bengkulu: Pustaka

Pelajar. 